\title{
NOTE
}

\section{Carp coccidiosis: activity of phagocytic cells from common carp infected with Goussia carpelli}

\author{
Dieter Steinhagen*, Katharina Hespe
}

Fachgebiet Fischkrankheiten und Fischhaltung, Tierärztliche Hochschule Hannover, Bünteweg 17, D-30559 Hannover, Germany

\begin{abstract}
Pronephric phagocytes from common carp Cyprinus carpio L. infected with the gut-dwelling coccidian Goussia carpelli showed enhanced phagocytic activity during the period of merogonic and gamogonic development of the parasite from Days 10 to 15 post exposure (PE) to the parasite. The respiratory burst activity was enhanced during excretion of oocysts at Days 15 to $25 \mathrm{PE}$. The addition of parasite lysates to assays resulted in an increase of phagocyte activity in cells from carp infected with gamogonic and sporogonic stages of the parasite and from carp which, at Day 35 PE, had recovered from $a G$ carpelli infection. The addition of immune serum sampled from fish at Days 5, 10, 15, 20, and 25 PE had no clear stimulatory effect on phagocyte activity. This suggests an activation of pronephric phagocytes on infection with the parasite. In carp with gamogonic and sporogonic parasite stages, activated macrophages show an increased cytotoxic reactivity, and activated macrophages rather than non-activated resident macrophages can be enhanced by opsonization with parasite molecules.
\end{abstract}

KEY WORDS: Goussia carpelli - Carp coccidiosis - Phagocyte activity $\cdot$ Respiratory burst activity

Goussia carpelli is a widespread gut-dwelling parasite of common carp Cyprinus carpio L. and ornamental koi carp from hatchery populations. The transmission of the parasite to uninfected carp usually occurs when the fish start feeding and involves fecal contamination and indirect transmission via tubificid oligochaetes (Steinhagen \& Körting 1990). In natural conditions, the main source of infection is pond sediment which contains high numbers of infective stages (Steinhagen \& Hespe unpubl.). In carp from northern German pond populations, intestinal epithelial cells commonly harbor merogonic, gamogonic and sporogonic developmental stages of $G$. carpelli 3 to $4 \mathrm{wk}$ posthatch. During this time, pathological changes of

\footnotetext{
-E-mail:dstein@fisch.tiho-hannover.de
}

intestinal tissue are observed in carp fry from natural populations, and the infection has been reported to cause high mortalities in stocks of juvenile goldfish (Kent \& Hedrick 1985), carp (Doflein \& Reichenow 1953), and ornamental koi carp fry (Paperna pers. comm.). Laboratory-infected carp fingerlings refused to feed and appeared listless, although no fish died (Steinhagen et al. 1997), and excreted oocysts, but then recovered from the infection about $3 \mathrm{wk}$ post initial exposure to the parasite (Jendrysek et al. 1994, Steinhagen 1994, Steinhagen et al. 1997).

The defense mechanisms of fish against coccidian parasites are not well understood (Davies \& Ball 1993). In Goussia carpelli infected carp, Lom \& Dykova (1992) and Jendrysek et al. (1994) observed an infiltration of granulocytes, lymphocytes and macrophages into infected tissue areas. Studnicka \& Siwicki (1990) found that neutrophil granulocytes from the blood of carp with a spontaneous $G$. subepithelialis infection showed increased phagocytic activities. In the immune system of fish, phagocytes play an important role as accessory and effector cells and possess the ability to migrate, phagocytose, and kill pathogens (for review, see Secombes \& Fletcher 1992). Phagocyte activity has been described as being crucial to the protection of fish against certain bacterial and parasitic antigens, e.g. from microsporidians (Dykova \& Lom 1980), and the modulation of phagocyte activity in a nonspecific manner or as a result of vaccination is thought to have an impact on disease susceptibility (Anderson 1992, Secombes 1994).

In the present communication, we examined phagocytosis and the respiratory burst activity (expressed as number of NBT-reducing cells; see 'Materials and methods') by phagocytes isolated from common carp during the course of a laboratory-induced Goussia carpelli infection, and the modulatory effects of parasite lysates and immune serum. 
Materials and methods. For infection experiments, carp of a single crossing $($ E20 $\times$ R8, Wageningen Agricultural University, The Netherlands) were used. The carp were bred and raised in the laboratory, and kept in coccidia-free glass tanks filled with tap water. Carp fry were fed initially with Artemia salina nauplii and 6 wk post hatch with commercial fish feed (Trouvit, The Netherlands)

Infection experiments: Carp 6 mo old (approx. 40 to $60 \mathrm{~g})$ were infected with Goussia carpelli as described previously (Steinhagen \& Körting 1990). Briefly, the fish were placed into an $80 \mathrm{l}$ tank contaminated with $10^{7}$ oocysts, kept for 24 to $48 \mathrm{~h}$, and then transferred to $80 \mathrm{l}$ glass tanks with tap water at a temperature of 20 to $24^{\circ} \mathrm{C}$. For controls, uninfected carp were kept in separate 80 i tanks under identical conditions. Carp were sequentially killed after laboratory infection 5 , $10,15,20,25$, and $30 \mathrm{~d}$ post exposure (PE) to the parasite; the pronephros was removed and cell suspensions were prepared. Smears from the gut mucosa were examined for the presence of parasite stages. At each interval, tissues from 5 infected and 5 control fish were processed individually.

Tissue preparation: Cell suspensions from pronephros were prepared as described by Rombout et al. (1993). Briefly, the carp were killed in a bath with tricaine ( $0.5 \mathrm{~g} \mathrm{l}^{-1}$ MS 222; Sandoz, Basle), exsanguinated and necropsied; the pronephros was collected in RPMI 1640 (+10\% distilled water, $10 \mathrm{IU}$ heparin $\mathrm{ml}^{-1}, 1 \%$ bovine serum albumin, BSA; pH 7.4; chemicals: Sigma, St. Louis, MO, USA). The tissue samples were forced through a nylon screen (100 $\mu \mathrm{m}$ pore diameter; Swiss Silk Bolting Cloth Mfg., Switzerland), washed twice with RPMI and resuspended in the same buffer. The cells were then layered onto a density gradient $\left(1.02 / 1.05 / 1.07 \mathrm{~g} \mathrm{ml}^{-1}\right.$; Percoll, Pharmacia, Sweden) and centrifuged for $25 \mathrm{~min}$ at $750 \times \mathrm{g}$. Macrophageenriched cell populations were collected from the 1.02/1.05 and 1.05/1.07 interfaces, washed 3 times in the same buffer and adjusted to $10^{6}$ viable cells per $\mathrm{ml}$ based on the exclusion of trypan blue. These suspensions contained 10 to $15 \%$ macrophages. Buffers and cells were kept on ice, and washing procedures were performed at $4^{\circ} \mathrm{C}$. To prevent the adhesion of macrophages to glass tubes, siliconized glassware (Sigmacote, Sigma) was used for tissue preparation.

Serum preparation: Blood from experimental and control carp was collected separately via caudal puncture into glass tubes, allowed to clot at room temperature for $2 \mathrm{~h}$, and the supernatant serum was removed.

Parasite Iysate preparation: Goussia carpelli oocysts were isolated and purified from intestines of infected carp as described previously (Steinhagen 1994), suspended with RPMI, and lysed by repeated freezing and thawing. Particles were removed from the lysate by centrifugation. The supernatant was sampled, the protein content determined according to Lowry (Holtzhauer 1988), and stored frozen $\left(-22^{\circ} \mathrm{C}\right)$ until use.

Phagocytosis assay: For collection of phagocytes, $25 \mu \mathrm{l}$ of the cell suspensions was dispensed into circles of immunofluorescence slides (BioMerieux, France) and incubated at $4^{\circ} \mathrm{C}$ for $1 \mathrm{~h}$ in a humid atmosphere to allow adherence of monocytes/macrophages. At the end of the incubation time, the slides were gently washed with RPMI. To the washed macrophage monolayers, $25 \mu \mathrm{l}$ of glutaraldehyde-fixed and Congo-redstained yeast cells opsonized with carp serum and suspended with RPMI (+1\% carp serum) or with parasite lysates $(+1 \%$ carp serum) were added and this was incubated at $25^{\circ} \mathrm{C}$ for $2 \mathrm{~h}$ in a humid atmosphere. For opsonization, the yeast cells were washed with RPMI + $1 \%$ serum from uninfected control carp, suspended with RPMI $+10 \%$ carp serum from non-infected or from experimental carp and incubated at $25^{\circ} \mathrm{C}$ for $1 \mathrm{~h}$, then washed and resuspended at a concentration of $4 \times$ $10^{8}$ cells $\mathrm{ml}^{-1}$ with RPMI $+1 \%$ serum from control carp. In these experiments 2 different immune sera were used: (1) serum obtained from the same fish from which the phagocytes were collected, and (2) serum collected from carp 18 to $20 \mathrm{~d}$ PE to the parasite. At the end of the incubation time the macrophages were washed thoroughly and the preparations were evaluated with phase contrast optics (Zeiss, Oberkochem, Germany). The percentage of cells with engulfed yeast cells (percent phagocytes) and the number of yeast cells engulfed were determined and a phagocytosis index was calculated as number of yeast cell engulfed/ number of macrophages counted. Each treatment was done in triplicate, and from each replicate 200 macrophages were evaluated.

Respiratory burst activity: To measure respiratory burst activity, a nitroblue tetrazolium (NBT) assay as described by Anderson (1992) was applied: Macrophage monolayers were washed with RPMI and then incubated with $25 \mu \mathrm{l}$ of $0.2 \%$ NBT in RPMI containing $1 \%$ carp serum and $4 \times 10^{8}$ latex beads $(1 \mu \mathrm{m}$ in diameter; Polysciences, Warrington, PA, USA) at $25^{\circ} \mathrm{C}$ for $2 \mathrm{~h}$. The latex beads were opsonized with serum from experimental carp or from uninfected controls as described above. At the end of the incubation time, the preparations were washed and evaluated microscopically by counting adherent cells with blue formazan precipitate.

Statistics: At each sample interval, measurements from infected carp were compared with those from uninfected controls by non-parametric statistics (rank sum test). Differences were considered to be significant at $\mathrm{p} \leq 0.05$.

Results. All carp exposed to Goussia carpelli oocysts became infected by the parasite. Intestinal scrapings 
of infected carp harbored merogonic developmental stages at Days 5 and 10, gamogonic and sporogonic stages at Day 15, and oocysts at Day $20 \mathrm{PE}$. At Days 25 and $30 \mathrm{PE}$, few or no oocysts were detected. Carp from control groups remained uninfected throughout the experiments.

The results of the phagocytosis and respiratory burst experiments are shown in Figs. 1 to 3. Phagocytes isolated from individual fish exhibited a high variability in their activity even though fish from a clearly defined source were used.

An infection of carp with the enteritic coccidia Goussia carpelli had a stimulatory effect on the activity of pronephric phagocytes. During merogonic and gamogonic development of the parasite, at Days 10 and 15 $\mathrm{PE}$, phagocytes from parasitized carp incorporated more yeast cells than uninfected controls (Fig. 1). At Day $10 \mathrm{PE}$, this difference in activity could be confirmed as statistically significant, but due to the high individual variability this failed at Day 15 PE $(p<0.08)$.

To monitor the respiratory burst activity, we determined the number of NBT-positive cells. From Days 18 to $25 \mathrm{PE}$ the number of NBT-positive cells was elevated (Fig. 2a). Statistically, the differences were significant at Day $18 \mathrm{PE}$, but again due to the high individual variability this failed at Day $25(p<0.07)$.

A previous incubation of yeast cells with serum from experimentally infected carp had no clear additional activating effects on pronephric phagocytes. No significant change in the mean number of NBT-reducing cells could be observed between assays with control serum, immune serum from the same fish as that from

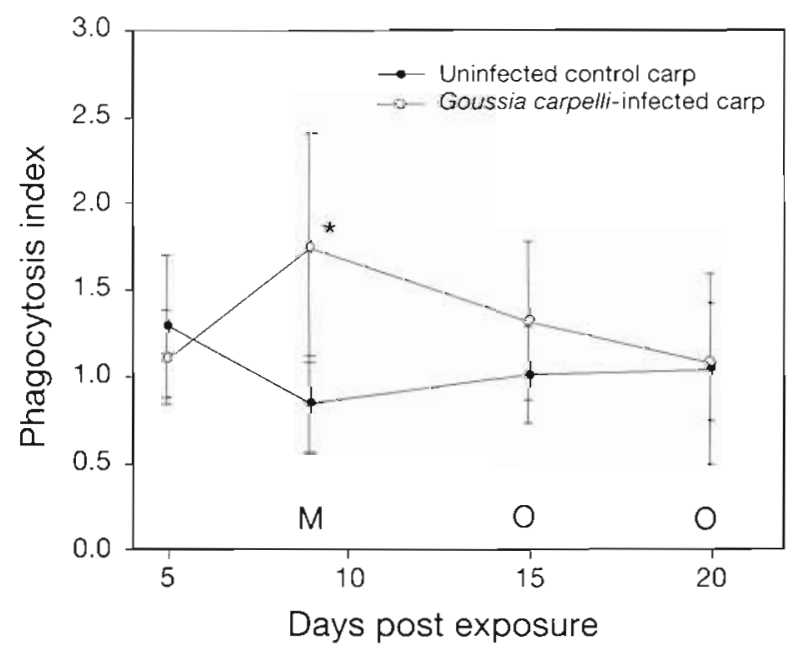

Fig. 1. Cyprinus carpio. Phagocyte index of pronephric macrophages from carp infected with Goussia carpelli. M: meronts; $\mathrm{O}$ : oocysts in intestinal scrapings. Mean values $\pm \mathrm{SD}$ of measurements from 5 fishes from 1 experiment out of a set of 2 experiments. - Statistically significant $(p<0.05)$ differences between the experiments
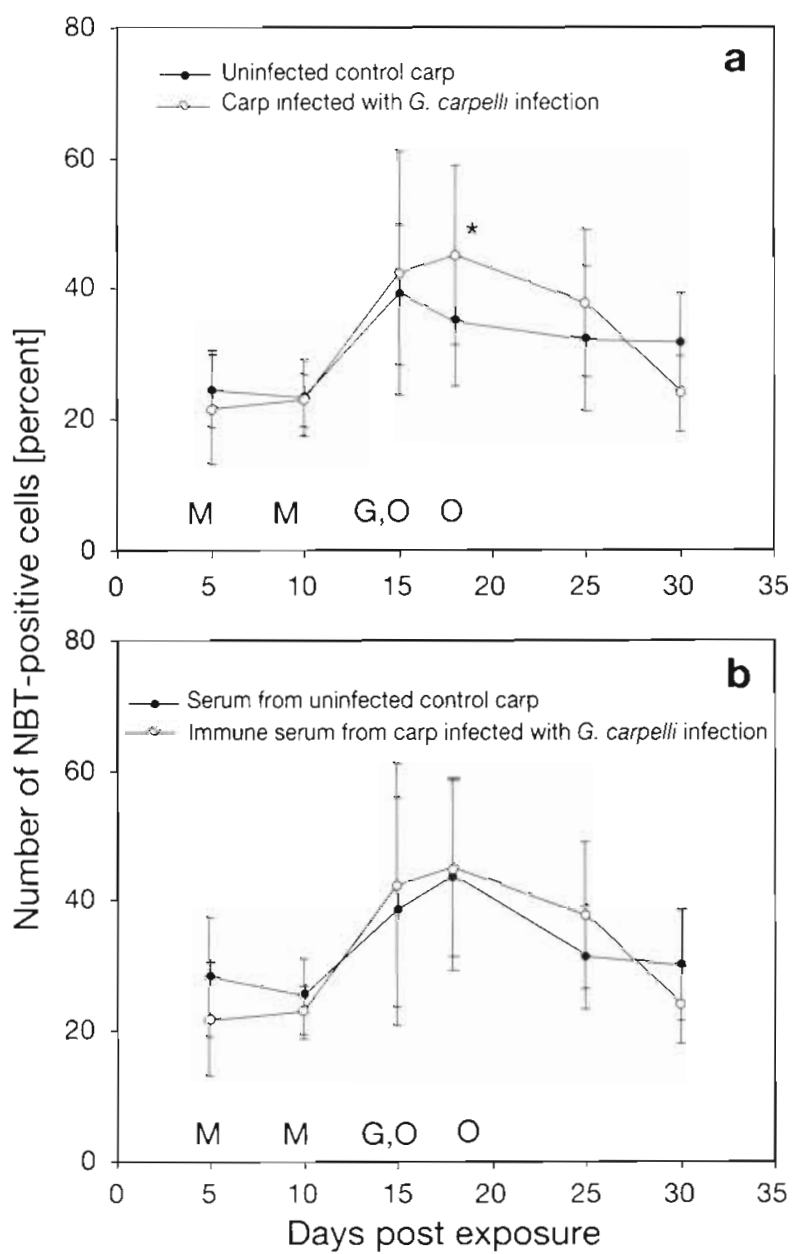

Fig. 2. Cyprinus carpio. NBT reduction of pronephric macrophages from carp infected with Goussia carpelli. (a) Cells from infected and control carp incubated with serum from non-infected carp. (b) Cells from infected carp incubated with serum from infected fish (see 'Materials and methods') and non-immune serum. $M$ : meronts; $G$ : gamonts; $O$ : oocysts in intestinal scrapings. Mean values $\pm S D$ of 5 fish from 1 experiment out of a set of 2 experiments. "Significant differences between treatment groups at $p<0.05$

which the phagocytes were collected (Fig. $2 b$ ), or serum obtained from fish 18 to $20 \mathrm{~d}$ PE (data not shown).

A supplementation of incubation media with Goussia carpelli lysates at a concentration of $10 \mathrm{ng} \mathrm{ml}^{-1}$ significantly increased the number of cells which incorporated yeast cells in macrophage monolayers obtained from carp infected with gamogonic and sprorogonic stages of G. carpelli (Days 8 to $10 \mathrm{PE}$ ) and from carp at Day $35 \mathrm{PE}$, which had already recovered from a G. carpelli infection (Fig. 3).

Discussion. Phagocytes are involved in the recognition and elimination of invading pathogens and damaged host cells. They are concerned with antigen trapping and processing (Vallejo et al. 1992). In the intestine, it was mainly intraepithelial macrophages 


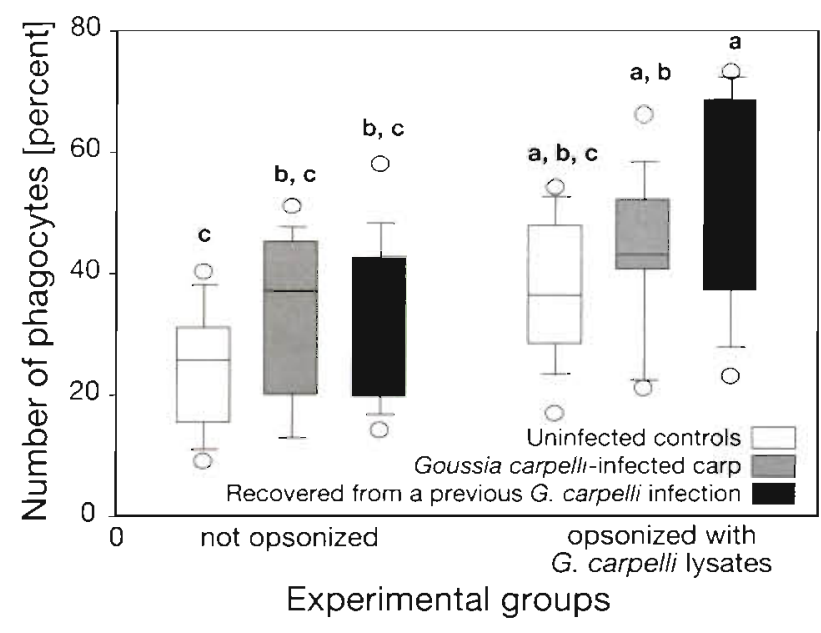

Fig. 3. Cyprinus carpio. Effect of Goussia carpelli lysates on the activity of pronephric phagocytes of carp. Mean values and range of the proportion of phagocytes in cell suspensions from 10 carp intected with $G$. carpelli at Days 8 to $10 \mathrm{PE}$ and 10 carp at Day $35 \mathrm{PE}$ which had recovered from a previous infection with $G$. carpelli. Significant differences $(p<0.05)$ between experimental groups are indicated by different letters. No statistically significant differences were found between treatment groups labelled with the same letter

from the second posterior gut segment that absorbed and transported soluble and particulate antigens (Rombout \& Berg 1989). These cells are thought to represent a major part of the well-developed gut immune system of teleost fish (Rombout et al. 1993) which enables the fish to respond to enterically delivered antigens by local mucosal and systemic immune reactions (Rombout et al. 1989, Ainsworth et al. 1995, Joosten et al. 1996). Oral delivery of Edwardsiella ictaluri antigens to channel catfish Ictalurus punctatus resulted in enhanced bacterial killing activities by pronephric neutrophils (Ainsworth et al. 1995).

In the present study, we examined effects of an infection with the enteritic parasite Goussia carpelli on the activity of pronephric phagocytes of carp. The phagocytotic activity of these cells was elevated during the period of merogonic and gamogonic development of the parasite (Days 10 to $15 \mathrm{PE}$ ), and the respiratory burst activity during the excretion of oocysts at Days 15 to $25 \mathrm{PE}$. This confirmed earlier observations by Studnicka \& Siwicki (1990), who reported increased phagocytic activity of neutrophils from the peripheral blood of carp with a spontaneous infection with the enteritic coccidian $G$. subepithelialis. It further indicates that activated macrophages with increased cytocidal capabilities occur at a later stage of parasite development. In mammalian and avian coccidiosis, phagocytic cells were observed to internalize sporozoite and merozoite parasite stages (Long 1993). In vitro studies on interactions of Eimeria falciformis and murine peritoneal macrophages demonstrated that lysis of internalized sporozoites occurred in immune macrophages and required both antibodies and complement (Bekhti \& Pery 1989). In acute infections with G. carpelli, macrophages infiltrated affected gut areas and internalized deteriorated host cells and coccidia (Jendrysek et al, 1994). In the present study, we observed a significantly elevated activity of pronephric phagocytes from infected carp during this period of parasite development (Day $10 \mathrm{PE}$ ).

Throughout the development of Goussia carpelli, serum from infected carp did not contain stimulatory factors compared with non-immune serum. This corresponds to observations on carp with Aeromonas salmonicida infections (Verburg-van Kemenade et al. 1996). Macrophages from bacteria-infected carp did not show a clearly enhanced respiratory burst activity, and incubation with immune serum had no additional stimulatory effect. In channel catfish immunized with Edwardsiella ictaluri antigens, the killing activity of naive neutrophils was enhanced when immune serum instead of naive serum was included in the assay. However, compared with the lytic activity of immune serum alone, the addition of cells did not increase the bacterial killing (Ainsworth et al. 1995). The killing activity of serum alone suggests that the immune serum did not induce an activation of the neutrophils.

Addition of formalin-killed bacteria to macrophage preparations resulted in a stimulation of NBT reduction in cells from Aeromonas salmonicida infected fish in a dose-dependent manner (Verburg-van Kemenade et al. 1996). In our experiments, the Goussia carpelli lysates increased the phagocytic activity of pronephros macrophages from infected or immune carp but not from naive fish. This indicates that parasite-derived molecules may modulate the activity of activated but not of non-activated resident macrophages from carp pronephros.

Acknowledgements. This study was financially supported by a DFG grant. S. H. Leenstra and G. Wiegertjes, Wageningen, The Netherlands, kindly provided fertilized carp eggs.

\section{LITERATURE CITED}

Ainsworth AJ, Rice CD, Xue L (1995) Immune response of channel catfish, Ictalurus punctatus (Rafinesque), after oral or intraperitoneal vaccination with particulate or soluble Edwardsiella ictaluri antigen. J Fish Dis 18:397-409

Anderson DP (1992) In vitro immunization of fish spleen sections and NBT phagocytic, PFC and antibody assays for monitoring the immune response. In: Stolen JS, Fletcher TC, Anderson DP, Kaattari SL, Rowley AF (eds) Techniques in fish immunology. Fish Immunology Technical Communication 2. SOS Publications, Fair Haven, NJ, p 79-87 
Bekhti K, Pery P (1989) In vitro interactions between murine macrophages and Eimeria falciformis sporozoites. Res Immunol 140:697-709

Davies AJ, Ball SJ (1993) The biology of fish coccidia. Adv Parasitol 32:293-366

Doflein F, Reichenow E (1953) Lehrbuch der Protozoenkunde, 6 th edn. Fischer Verlag, Stuttgart

Dykova I, Lom J (1980) Tissue reactions to microsporidian infections in fish. J Fish Dis 3:265-283

Holtzhauer M (1988) Biochemische Labormethoden. SpringerVerlag, Berlin

Jendrysek S, Steinhagen D, Körting W, Drommer W (1994) Carp coccidiosis: intestinal histo- and cytopathology under Goussia carpelli infection. Dis Aquat Org 20:171-182

Joosten PHM, Kruijer WJ, Rombout JHWM (1996) Anal immunisation of carp and rainbow trout with different fractions of a Vibrio anguillarum bacterin. Fish Shellfish Immunol 6:541-551

Kent ML, Hedrick RP (1985) The biology and associated pathology of Goussia carpelli (Leger and Stankovitch) in goldfish Carassius auratus (Linnaeus). Fish Pathol 20 : $485-494$

Lom J, Dykova 1 (1992) Protozoan parasites of fishes. Developments in Aquaculture and Fisheries Sciences, Vol 26 Elsevier, Amsterdam

Long PL (1993) Avian coccidiosis. In: Kreier JP (ed) Parasitic Protozoa, Vol 4, 2nd edn. Academic Press, San Diego, p 1-88

Rombout JHWM, Berg AA van den (1989) Immunological importance of the second gut segment of carp. I. Uptake and processing of antigens by epithelial cells and macrophages. J Fish Biol 35:13-22

Rombout JHWM, Berg AA van den, Berg CTGA van den, Witte P, Eqberts E (1989) Immunological importance of the

Editorial responsibility: Otto Kinne,

Oldendort/Luhe, Germany second gut segment of carp. III. Systemic and/or mucosal responses after immunization with soluble or particulate antigen. J Fish Biol 35:179-186

Rombout JHWM, Taverne-Thiele JJ, Villema Ml (1993) The gut associated lymphoid tissue (GALT) of carp (Cyprinus carpio L): an immunocytochemical analysis. Dev Comp Immunol 17:55-66

Secombes CJ (1994) Enhancement of fish phagocyte activity. Fish Shellfish Immunol 4:421-436

Secombes CJ, Fletcher TC (1992) The role of phagocytes in the protective mechanisms of fish. Annu Rev Fish Dis 2: $53-71$

Steinhagen D (1994) Methods for isolation and purification of Goussia carpell (Protozod, Coccidia) developmental stages from the intestine of infected common carp (Cyprinus carpio L.). Bull Eur Assoc Fish Pathol 14:200-203

Steinhagen D, Körting W (1990) The role of tubificid oligochaetes in the transmission of Goussia carpelli. J Parasitol $76: 104-107$

Steinhagen D, Oesterreich B, Körting W (1997) Carp coccidiosis: clinical and hematological observations on carp under Goussia carpelli infection. Dis Aquat Org 30:137-143

Studnicka M, Siwicki A (1990) The nonspecific immunological response in carp (Cyprinus carpio L.) during natural infection with Eimeria subepithelialis. Bamidgeh 42:18-21

Vallejo AN, Miller NW, Clem LW (1992) Antigen processing and presentation in teleost immune responses. Annu Rev Fish Dis 2:73-89

Verburg-van Kemenade BML, Daly JG, Groeneveld A, Wiegertjes GF (1996) Multiple regulation of carp (Cyprinus carpio L.) macrophage and neutrophilic granulocytes by serum factors: influence of infection with atypical Aeromonas salmonicida. Vet Immunol Immunopathol 51: $189-200$

Submitted: July 10, 1997; Accepted: September 22, 1997

Proofs received from author(s): October 31, 1997 